\title{
Review \\ AXL Receptor in Cancer Metastasis and Drug Resistance: When Normal Functions Go Askew
}

\author{
Almira Auyez ${ }^{1}$, A. Emre Sayan ${ }^{2}$, Marina Kriajevska ${ }^{1,3}$ and Eugene Tulchinsky ${ }^{1,3, *}$ \\ 1 Department of Biomedical Sciences, Nazarbayev University School of Medicine, Nur-Sultan 020000, \\ Kazakhstan; almira.auyez@nu.edu.kz (A.A.); marina.kriajevska@nu.edu.kz (M.K.) \\ 2 Cancer Sciences Division, University of Southampton, Southampton SO16 6YD, UK; A.E.Sayan@soton.ac.uk \\ 3 Department of Genetics and Genome Biology, University of Leicester, Leicester LE1 7RH, UK \\ * Correspondence: et32@le.ac.uk or eugene.tulchinsky@nu.edu.kz
}

check for updates

Citation: Auyez, A.; Sayan, A.E.; Kriajevska, M.; Tulchinsky, E. AXL Receptor in Cancer Metastasis and Drug Resistance: When Normal Functions Go Askew. Cancers 2021, 13, 4864. https://doi.org/10.3390/ cancers13194864

Academic Editor: Huey-Jen Lin

Received: 11 August 2021

Accepted: 21 September 2021

Published: 28 September 2021

Publisher's Note: MDPI stays neutral with regard to jurisdictional claims in published maps and institutional affiliations.

Copyright: (c) 2021 by the authors. Licensee MDPI, Basel, Switzerland. This article is an open access article distributed under the terms and conditions of the Creative Commons Attribution (CC BY) license (https:// creativecommons.org/licenses/by/ $4.0 /)$.
Simple Summary: AXL is a member of the TAM (TYRO3, AXL, MER) family of receptor tyrosine kinases. In normal physiological conditions, AXL is involved in removing dead cells and their remains, and limiting the duration of immune responses. Both functions are utilized by cancers in the course of tumour progression. Cancer cells use the AXL pathway to detect toxic environments and to activate molecular mechanisms, thereby ensuring their survival or escape from the toxic zone. AXL is instrumental in controlling genetic programs of epithelial-mesenchymal and mesenchymal-epithelial transitions, enabling cancer cells to metastasize. Additionally, AXL signaling suppresses immune responses in tumour microenvironment and thereby helps cancer cells to evade immune surveillance. The broad role of AXL in tumour biology is the reason why its inhibition sensitizes tumours to a broad spectrum of anti-cancer drugs. In this review, we outline molecular mechanisms underlying AXL function in normal tissues, and discuss how these mechanisms are adopted by cancers to become metastatic and drug-resistant.

Abstract: The TAM proteins TYRO3, AXL, and MER are receptor tyrosine kinases implicated in the clearance of apoptotic debris and negative regulation of innate immune responses. AXL contributes to immunosuppression by terminating the Toll-like receptor signaling in dendritic cells, and suppressing natural killer cell activity. In recent years, AXL has been intensively studied in the context of cancer. Both molecules, the receptor, and its ligand GAS6, are commonly expressed in cancer cells, as well as stromal and infiltrating immune cells. In cancer cells, the activation of AXL signaling stimulates cell survival and increases migratory and invasive potential. In cells of the tumour microenvironment, AXL pathway potentiates immune evasion. AXL has been broadly implicated in the epithelialmesenchymal plasticity of cancer cells, a key factor in drug resistance and metastasis. Several antibody-based and small molecule AXL inhibitors have been developed and used in preclinical studies. AXL inhibition in various mouse cancer models reduced metastatic spread and improved the survival of the animals. AXL inhibitors are currently being tested in several clinical trials as monotherapy or in combination with other drugs. Here, we give a brief overview of AXL structure and regulation and discuss the normal physiological functions of TAM receptors, focusing on AXL. We present a theory of how epithelial cancers exploit AXL signaling to resist cytotoxic insults, in order to disseminate and relapse.

Keywords: AXL; TAM receptors; epithelial-mesenchymal plasticity; drug resistance; metastasis

\section{Introduction}

Metastatic propensity and drug resistance are two fundamental features of cancer, which cause treatment failure and death of cancer patients. These two key features are intrinsically related. A proportion of cancer cells (so-called drug-tolerant persisters or DTPs) survive exposure to a drug and give rise to cancer relapse. On the other hand, during the metastatic process, cells are likely to utilize the same basic survival mechanisms 
to adapt to the hostile environment of foreign tissues. Survival and invasion are dependent on signaling pathways acting downstream of various surface receptors, including receptor tyrosine kinases (RTKs). In many cases, gain-of-function mutations in RTK-encoding genes, and their amplification or overexpression are associated with metastatic propensity and drug resistance. In various cancer types, patients' survival is improved by drugs targeting RTKs as mono- or combination therapy. Understanding the biology of RTKs in normal and cancerous tissues is essential for tailoring therapeutic approaches. The TAM family of RTKs has emerged as an important driver of cancer, and among this family, AXL has attracted the most attention as a molecule when expressed possesses prognostic value in several cancer types, including breast, ovarian, lung, and pancreatic cancer [1,2]. Moreover, preclinical studies have convincingly demonstrated AXL involvement in metastasis and resistance to various anti-cancer agents (see below). Several ongoing clinical trials have investigated the therapeutic benefits of AXL inhibition [3,4]. The exclusive role of AXL in cancer progression is likely associated with AXL normal function in clearance of apoptotic cells and immunosuppression. In addition, the implication of AXL in epithelial cell plasticity in tumours explains its role in drug resistance and metastasis. Here, we discuss AXL function in normal homeostasis and review the current literature on the underlying mechanisms to explain the distinctive role of this receptor in cancer biology.

\section{Overview of the Structure and Regulation of AXL Receptor}

\subsection{Structural Features of TAM Receptors and Their Interactions with the Ligands}

AXL and two related proteins: TYRO3 and MER are single-pass transmembrane receptors. AXL ectodomain contains two fibronectin type III-like and two immunoglobulinlike repeats, with the latter responsible for the interactions with the ligands, Growth Arrest-Specific protein 6 (GAS6) and Protein S1 (PROS1) (Figure 1). As it will be discussed later, interactions between ligands and phosphatidylserine (PtdSer) are required for the full activation of TAM receptors and their functions in normal tissues and tumour microenvironment. In addition to GAS6 and PROS1, three other proteins have been identified as potential ligands of TAM receptors, Galectin-3, TUBBY, and TUBBY-like protein 1 (TULP1) [5-7]. However, their role in physiological processes regulated by TAM receptors is currently underexplored. The homology is not evenly distributed over TAM protein sequences; it is very high within the kinase domains (60-66\% identity) and much lower in the ectodomains (30-35\% identity). Structural differences in ectodomains of TAM receptors reflect their functional divergence and different affinities to the ligands. It has been broadly accepted that PROS1 binds TYRO3 and MER only, and GAS6 interacts with all three TAM proteins with the highest binding affinity to AXL [8]. However, a recent study has shown that PROS1 binds and activates AXL in glioma spheroids [9].

\subsection{AXL Receptor Regulation by Proteolytic Cleavage}

AXL expression is regulated at the level of gene transcription, by miRNA (will be discussed in the following sections), and at the posttranslational level by ectodomain shedding. The receptor is cleaved by proteolytic enzymes, ADAM10 and ADAM17, in the area immediately adjacent to the transmembrane helix, leading to the release of $\sim 80 \mathrm{kDa}$ ectodomain into the extracellular milieu $[10,11]$. The shed ectodomain, termed soluble AXL (sAXL), can bind AXL ligand GAS6 and provide negative feedback by interfering with AXL activation. In addition, AXL receptor is a substrate for $\gamma$-secretase. After shedding the extracellular part, $\gamma$-secretase cleaves the remaining part within the transmembrane domain, releasing intracellular AXL fragment. This fragment can be transported to the nucleus via a nuclear localization signal (NLS) located next to the transmembrane domain [10]. Nuclear AXL was detected in cultured non-small cell lung cancer cells [12], in schwannoma and melanoma samples by immunohistochemistry $[13,14]$. Recently, a direct interaction between AXL and TP53 gene promoter DNA has been reported to repress TP53 gene transcription in mesothelioma cells [15]. The mechanism of incorporation of nuclear AXL into chromatin surrounding TP53 promoter remains obscure. Although NLS adjacent to 
the transmembrane domain is present in TYRO3, but not in MER. Nuclear localization of either receptor was reported in leiomyosarcoma and acute lymphoblastic leukemia, respectively $[16,17]$.

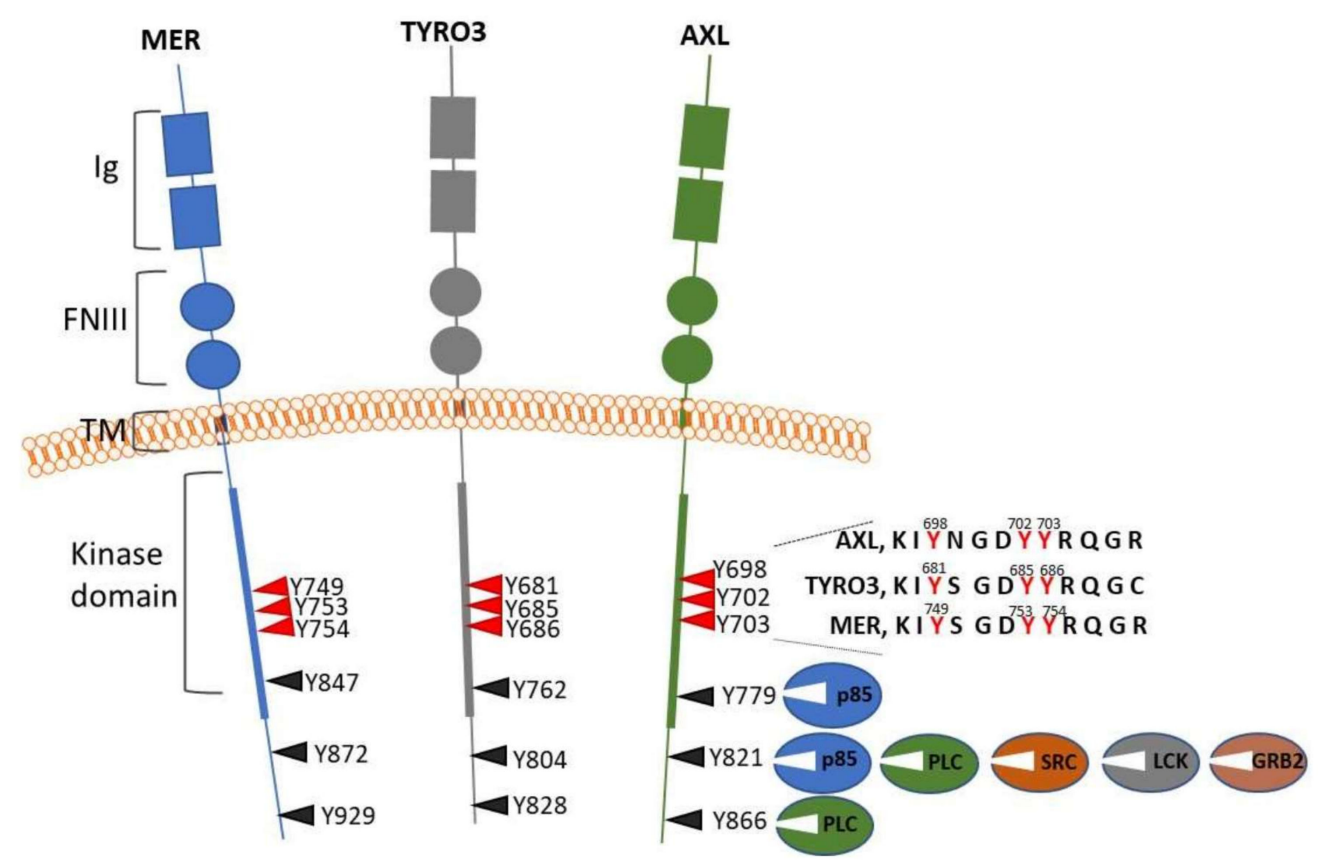

Figure 1. A scheme portraying TYRO3, MER and AXL receptors. Conserved domains, fibronectin type III (FNIII), immunoglobulin (Ig)-like, transmembrane (TM), and kinase domains are shown. Phosphorylated tyrosines within kinase domains and distal cytoplasmic regions are indicated. The scheme shows $\mathrm{SH} 2$-containing docking proteins interacting with AXL C-terminal phosphotyrosines. p85, regulatory PI3K subunit; PLC, phospholipase C; SRC, cellular tyrosine kinase c-SRC; LCK, lymphocyte-specific protein tyrosine kinase; GRB2, growth factor receptor-bound protein 2.

\section{Overview of AXL-Regulated Signaling}

\subsection{Docking Sites for Signaling Proteins}

Binding a ligand results in AXL receptor dimerization and cross-phosphorylation at several tyrosine residues positioned within the kinase autoregulatory loop (Y698, Y702 and Y703) and distal portion of the cytoplasmic domain (Y779, Y821 and Y866) (Figure 1) [18,19]. The impact of the autoregulatory loop phosphorylation has not been investigated in the context of AXL, but mutating homologous residues to phenylalanines, within MER, strongly repressed or entirely abrogated protein kinase activity [20]. Phosphorylation at Y779, Y821 and Y866 generated docking sites attracting signaling molecules with SH2 domains. Specifically, phosphorylation at Y821 recruited a number of effectors, including phospholipase $C \gamma$, phosphatidylinositol 3-kinase (PI3K) regulatory subunits $\mathrm{p} 85 \alpha$ and $\beta$, cellular tyrosine kinase c-SRC (SRC), lymphocyte-specific protein tyrosine kinase (LCK) and growth factor receptor-bound protein 2 (GRB2). Phosphorylated Y779 or Y866 represented docking sites for $\mathrm{p} 85 \alpha / \beta$ and phospholipase C, respectively [19] (Figure 1). Therefore, the engagement of AXL receptors may lead to the activation of critical pathways implicated in cell survival and proliferation, mitogen- activated protein kinases (MAPK), PI3K, protein kinase C (PKC), and SRC.

\subsection{AXL Dimerization Partners and Diversification of Downstream Signaling}

In addition to homodimerization, AXL receptors are able to heterodimerize with TYRO3, leading to cross-phosphorylation and activation of downstream PI3K and MAPK/ERK signaling pathways [21,22]. AXL also interacts with the more distantly related receptors, such as epidermal growth factor receptor (EGFR), human epidermal growth factor receptor 2 (HER2), tyrosine-protein kinase Met (cMET), and platelet-derived growth factor 
receptor (PDGFR) [23-27]. The data indicate that AXL may trigger phosphorylation of other receptors and stimulate downstream signaling in a cell type-specific fashion. For example, in esophageal squamous cell carcinoma cells, AXL directly binds and phosphorylates EGFR in an EGF-independent mode. This leads to the activation of the mechanistic target of rapamycin (mTOR) via PKC without PI3K/AKT involvement. Subsequently, AXL mediates a bypass of the PI3K-AKT module, leading to the development of resistance to PI3K inhibition [25]. In ovarian cancer cells, the interaction between AXL and EGFR family members or cMET is stimulated by GAS6. It results in the phosphorylation of interacting receptors, ERK pathway activation, and enhanced cell motility [26]. Crosstalk between vascular endothelial growth factor receptor 2 (VEGFR2) and AXL has a different configuration, and involves SRC family kinases (SFK). In endothelial cells, AXL does not phosphorylate VEGFR2. Instead, in vascular endothelial growth factor A (VEGF A)-treated cells, VEGFR2 activates SFK, which phosphorylates AXL at Y779 and Y821 in GAS6-independent manner. This cross-talk stimulates ERK via VEGFR2 and PI3K-AKT signaling through $\mathrm{AXL}$, with both pathways being important for corneal neovascularization [28]. Therefore, the configuration of AXL-regulated molecular networks is cell type-specific and depends on the repertoire of co-expressed receptors, availability of GAS6 or other ligands, and differentiation status of cells.

\section{AXL Functions in Normal Tissues. Lessons from Mice}

Although AXL becomes detectable in embryonic tissues at day 12.5 after fertilization, $\mathrm{AXL}^{-/-}$and TAM triple knockout mice are viable and fertile. However, $\mathrm{TAM}^{-/-}$animals develop various abnormalities after birth, including autoimmune disorders, blindness, and male infertility $[29,30]$.

\subsection{Defective Efferocytosis in Immune System of $\mathrm{TAM}^{-/-}$Mice Results in Autoimmunity}

AXL is present in a wide spectrum of cells in adult tissues, including dendritic cells, macrophages, and platelets [31]. A primary cause of abnormalities in TAM triple knockout animals is the defective clearance of apoptotic cells and their accumulation in mouse tissues. Impaired phagocytosis of apoptotic cells in the immune system is largely responsible for the autoimmune phenotype observed in TAM-deficient mice [32]. The clonal selection of immune cells generates large amounts of dying cells, which undergo clearance by macrophages, dendritic cells, and other phagocytes through efferocytosis. Cells undergoing apoptosis experience modifications of autoantigens, disintegration of their membranes, and leakage of cellular contents (so-called secondary necrosis) [33]. The release of autoantigenic potentially toxic danger signals by dying immune cells, which were not cleared by phagocytes, drives autoimmune reactions. This leads to rheumatoid arthritis and systemic lupus erythematosus in humans, and autoimmune phenotype in TAM-deficient mice [33,34].

\subsection{Blindness and Male Infertility in TAM Knockout Mice}

Similar to the autoimmune phenotype, blindness and male infertility in TAM knockout mice are caused by the defects in efferocytosis. Pathology in the retina of TAM triple knockout mice is caused by functional inactivation of a specialized type of phagocytes containing TAM receptors-retinal pigment epithelial cells (RPE). These cells phagocytose the outer segments of retinal photoreceptors, and thereby remove toxic oxidative phototransduction products. Impairing the function of RPE by TAM knockout leads to widespread apoptosis in the retina, retinal dystrophy, and blindness [34]. A very similar retinal phenotype was observed in mice with combined deletion of genes encoding both TAM ligands, pros1 and gas6, further demonstrating that TAM signaling is indispensable for apoptotic cell clearance in the retina [35]. Pathology in the retina is mostly attributed to the inactivation of MER. Retinal phenotypes are similar in $\mathrm{MER}^{-/-}$and triple $\mathrm{TAM}^{-/-}$mice, but absent in AXL or TYRO3 single knockouts [34].

Phagocytosis in the testis is predominantly carried out by Sertoli cells. These TAMexpressing phagocytes are responsible for the clearance of abundant dead germ cells 
generated during spermatogenesis. The inactivity of Sertoli cells in $\mathrm{TAM}^{-/-}$mice lead to the accumulation of apoptotic cells in seminiferous tubules where spermatozoa are formed, whereby subsequent male infertility results [32].

\subsection{AXL Stimulates Efferocytosis by Regulating Cytoskeletal Dynamics}

Efferocytosis performed by dendritic cells and macrophages is predominantly dependent on AXL and MER, respectively [36]. GAS6 and PROS1 bind TAM receptors at 2:2 stoichiometry, but the physical availability of the ligand is not sufficient to ensure biological functions of the receptors. N-terminal $\gamma$-carboxyglutamic acid-rich (GLA) domain of GAS6 undergoes vitamin K-dependent carboxylation, and this modification stimulates the interaction of the ligand with PtdSer in plasma membranes. In normal circumstances, flippases ensure that PtdSer is located exclusively in the inner leaflets of plasma membranes. However, the cleavage of flippases at early stages of apoptosis results in the externalization of PtdSer in dying cells and apoptotic bodies [37]. Externalized PtdSer represents eat-me signals for macrophages and other phagocytes. AXL and MER exposed on the surface of phagocytes interact with their ligands GAS6 and PROS1 bound to PtdSer-rich membranes of target objects. In addition to TAM receptors and their ligands, other receptors and protein complexes are involved in forming contacts between phagocytes and their targets [38]. Those include direct PtdSer receptors, T-cell immunoglobulin, and mucin domain-containing molecules (TIMs) and $\alpha \mathrm{v} \beta 3$ or $\alpha \mathrm{v} \beta 5$ integrins binding to PtdSer-interacting ligand, the milk fat globule-EGF Factor 8 (MFG-E8). The binding of phagocytes to their targets initiates membrane ruffling, formation of longer protrusions with subsequent engulfment of phagocytized objects. Underlying cytoskeletal reorganization is regulated by the concerted action of several small GTPases, including RAC1 and RHOG $[39,40]$. The guanine exchange factor Dedicator Of CytoKinesis 180 (DOCK180) in a complex with scaffold proteins EnguLfment and MOtility 1 or 2 (ELMO1 or ELMO2) are responsible for the spatiotemporal activation of RAC1, membrane ruffling, engulfment, and phagocytosis $[38,40]$.

\subsection{AXL Limits the Innate Immune Response}

In addition to the stimulation of phagocytosis, TAM receptors, and in particular AXL, protect tissues from autoimmune disorders by limiting the duration of the innate immune response. The activation of Toll-like receptors (TLR) in macrophages and dendritic cells by endogenous danger signals induces an inflammatory response, which is attenuated via the activation of suppressor of cytokine signaling proteins (SOCS) 1 and 3. These inhibitors of Janus kinases/signal transducer and activator of transcription proteins (JAK/STATs) signaling are components of E3 ubiquitin ligase complexes, degrading adaptor molecules, which are required for the TLR pathway activation [41]. In dendritic cells, the expression of SOCS1/3 proteins depends on the presence of AXL, and is driven by a pathway involving STAT1, AXL/IFN $\alpha, \beta$ receptor (IFNAR) complex and GAS6 [42]. The inactivation of this immunosuppressive pathway, in combination with the defects in efferocytosis, is a key determinant of the autoimmune phenotype in $\mathrm{TAM}^{-/-}$mice.

\section{AXL and Cancer Cell Motility. Is Efferocytic Machinery Hijacked by Cancer Cells?}

\subsection{Motile Cancer Cells May Utilize DOCK180-ELMO Signaling Implicated in Efferocytosis}

In cancerous tissues, apoptotic cells are commonly cleared by the professional phagocytes expressing TAM receptors, namely dendritic cells and macrophages. However, nonprofessional phagocytes, such as tumour cells, can also engulf and ingest both dying [43,44] and living cells [45]. TAM receptors seem to participate in the non-professional clearance of apoptotic cells in cancer. The ectopic expression of MER in MCF10A and several cancer cell lines stimulate efferocytosis in vitro [44]. AXL is overexpressed in cells of solid tumours suggesting that GAS6-AXL-DOCK180-ELMO pathway may theoretically enable cancer cells to clear tumour tissues from apoptotic corpses. To our knowledge, this assumption has not been addressed so far. However, the data indicate that motile cancer cells may rely 
on this pathway to drive cytoskeletal dynamics. Indeed, in breast cancer cell lines, AXL physically interacts and phosphorylates ELMO1/2 at two tyrosine residues, and this is required for GAS6-induced RAC1 activation and cell invasiveness [46]. As discussed above, AXL may stimulate signaling pathways via crosstalk with other RTKs, and in addition to GAS6 other ligands, may activate RAC1 via AXL-ELMO-DOCK180 signaling module. At least one example of GAS6-independent and AXL-dependent activation of RAC1 has been reported. The treatment of glioblastoma cells with Hepatocyte Growth Factor (HGF) resulted in cMET-AXL co-clustering, AXL phosphorylation at Y779, recruitment of ELMODOCK180 complex, RAC1 activation, reorganization of the cytoskeleton, and enhanced cell motility [47]. The assumption that AXL is involved in different cell motility-inducing pathways, initiated by various growth factors, is in line with in vitro studies demonstrating that targeting AXL by RNA interference or AXL inhibitors diminished cell migration. These observations were made in different cell lines, derived from the pancreatic, breast, bladder, NSCLC, thyroid cancer, and liposarcoma [48].

In addition to AXL-ELMO-DOCK180, other AXL-activated pathways stimulate cell motility and invasiveness in vitro. In particular, in hepatocellular carcinoma cells, AXL induces cell migration via activation of PI3K, and subsequent AKT- and GTPase-independent stimulation of p21 (RAC1) activated kinase 1 (PAK1), a critical kinase implicated in cytoskeleton remodeling and control of directional motility [49]. In addition to the direct regulation of cytoskeletal processes, AXL was reported to stimulate cell motility by increasing the turnover of focal adhesions [50]. Mechanistically, this novel pathway represents direct phosphorylation of the scaffold protein, neural precursor cell expressed, developmentally down-regulated 9 (NEDD9) by AXL, the recruitment and phosphorylation of other signaling proteins, such as Paxillin, and destabilization of cell adhesions leading to motile cell phenotype. Understanding whether the elements of this pathway are also implicated in efferocytosis downstream of integrins and TAM receptors remains to be explored.

\subsection{Are Exosomes in Tumour Microenvironment Involved in AXL-Induced Cell Migration?}

The activation of AXL signaling by PtdSer-containing membranes is not limited to apoptotic cells. Apoptotic debris is not the sole source of externalized PtdSer in both normal and pathological conditions. Small extracellular vesicles (sEVs) or exosomes are roughly $100 \mathrm{~nm}$ particles produced by platelets, other types of normal cells, as well tumour cells. sEVs play an important role in intercellular communications in normal tissues, and in tumour-stroma crosstalk in cancer [51]. Outer leaflets of sEVs membranes are enriched for PtdSer [52], which is compatible with the hypothesis that TAM receptors are involved in signaling pathways initiated by sEVs [53]. Indeed, sEVs isolated from serum promoted migration of prostate, colon, lung, or breast cancer cells in vitro by activating TYRO3 in the presence of PROS1 [54]. sEVs-activated migration via TYRO3 is mediated by RHOAROCK2 pathway, and inactivation of cofilin via phosphorylation. Studies have not yet been conducted to explore whether the availability of ligands determines which TAM receptor is activated by sEVs. Perhaps, in the bloodstream where the concentration of PROS1 is much higher than GAS6 [55], TYRO3 is primarily responsible for sEVs-induced pathways in circulating tumour cells. It is possible that in tumour microenvironment, where the level of GAS6 is high $[56,57]$, AXL takes a central stage.

\section{AXL and Drug Resistance in Cancer}

\subsection{Survival in Toxic Conditions (Analogy with Professional Phagocytes)}

The clearance of apoptotic cells often occurs in toxic environments where professional phagocytes must survive and perform their functions. The engagement of TAM ligands with PtdSer on the surface of apoptotic cells allows phagocytes to sense toxicity and activate pro-survival mechanisms, including canonical PI3K-AKT and RAS-MAPK pathways. By hijacking TAM-activated pathways, cancer cells acquire the capability to survive when they detect early signs of apoptosis in the environment. Accordingly, numer- 
ous studies identify TAM-initiated pathways, and in particular, GAS6/AXL signaling as a mechanism of acquired resistance to chemo-, radio-, immune-, and targeted therapies. As AXL has been recognized as a prospective therapeutic target, several small molecule inhibitors (AXLi) with various degrees of selectivity or antibody-based inhibitors have been developed $[3,4,58]$. AXL inactivation occurs, either by the inhibitors or through RNA interference sensitized cancer cells to gamma-irradiation, antimitotic, and DNA damaging compounds in vitro. The application of AXLi-enhanced cytotoxic and anti-tumour effects of compounds in vitro target RTKs, EGFR, HER2, PDGFR, cMET, VEGFR, and cKIT [48,59]. Moreover, AXL inhibition has a strong potential to overcome therapy resistance in vivo. This has been shown in various preclinical models of solid tumours, including breast, lung, pancreatic, ovarian, esophageal, head and neck cancer, malignant melanoma, and brain tumours. Targeting AXL were shown to sensitize tumours to various types of therapies, including DNA damaging agents, EGFR, VEGFR, HDAC, G2/M checkpoint, and immune checkpoint inhibitors (Table 1).

Table 1. Targeting AXL signaling sensitizes solid tumours to various therapies in vivo.

\begin{tabular}{|c|c|c|c|c|c|}
\hline Cancer Type & Type of Study & $\begin{array}{l}\text { Method of AXL } \\
\text { Inhibition }\end{array}$ & Therapeutic Agent & Drug Class & Reference \\
\hline Breast cancer & $\left(^{*}\right) \mathrm{CDX}$ & mAb (YW327.6S2) & Anti-VEGF mAb & VEGFR-Targeted therapy & [60] \\
\hline Breast cancer & $\begin{array}{l}\text { Cell lines-derived } \\
\text { xenografts (CDX) }\end{array}$ & AXL shRNA, AXLi (R428) & Doxorubicin & Chemotherapy & [61] \\
\hline Ovarian cancer & Mouse CDX & AXLi (R428) & Anti-PD-1 mAb & Immunotherapy & [62] \\
\hline Lung cancer & CDX & mAb (YW327.6S2) & Erlotinib & EGFR-Targeted therapy & [60] \\
\hline Lung cancer & CDX & mAb (YW327.6S2) & $\begin{array}{l}\text { Paclitaxel + } \\
\text { Carboplatin }\end{array}$ & Chemotherapy & [60] \\
\hline Lung cancer, NSCLC & CDX & AXL shRNA, AXLi & Erlotinib & EGFR-targeted therapy & [63] \\
\hline Lung cancer, SCLC & CDX & AXLi (TP0903) & AZD1775 & WEE1-targeted therapy & [64] \\
\hline $\begin{array}{l}\text { Lung cancer, breast } \\
\text { cancer }\end{array}$ & $\begin{array}{l}\text { Mouse CDX, orthotopic } \\
\text { model for breast cancer }\end{array}$ & TAMi (Sitravatinib) & $\begin{array}{l}\text { Anti-PD-1 mAb } \\
\text { (Nivolumab) }\end{array}$ & Immunotherapy & [65] \\
\hline Lung cancer, NSCLC & CDX, $(* *)$ PDX & AXLi (NPS1034) & Osimertinib, & EGFR-targeted therapy & [66] \\
\hline Lung cancer, NSCLC & Human CDX & AXLi (ONO-7475) & Osimertinib & EGFR-targeted therapy & [67] \\
\hline $\begin{array}{c}\text { Esophageal } \\
\text { adenocarcinoma }\end{array}$ & Mouse CDX & AXLi (R428) & Epirubicin & Chemotherapy & [68] \\
\hline Pancreatic cancer & $\begin{array}{c}\text { Transgenic model } \\
\text { (Kras } \\
\text { CdkL-G12D; } \\
\text { Cdkn2ax/lox; Ptf1a } \mathrm{a}^{\text {lore/+ }} \text { ); } \\
\text { orthotopic model }\end{array}$ & AXLi (R428) & Gemcitabine & Chemotherapy & [69] \\
\hline $\begin{array}{l}\text { Head and Neck } \\
\text { Cancer }\end{array}$ & PDX & AXLi (R428) & $\begin{array}{l}\text { Cetuximab or } \\
\text { radiation }\end{array}$ & $\begin{array}{l}\text { EGFR-targeted therapy or } \\
\text { radiotherapy }\end{array}$ & [70] \\
\hline $\begin{array}{l}\text { Cutaneous } \\
\text { melanoma }\end{array}$ & PDX & $\begin{array}{c}\left({ }^{* * *}\right) \text { AXL-107-MMAE (or } \\
\text { EnaV) }\end{array}$ & $\begin{array}{l}\text { Vemurafenib + } \\
\text { Trametinib }\end{array}$ & $\begin{array}{l}\mathrm{BRAF}^{\mathrm{V} 600 \mathrm{E}}+\mathrm{MEK}- \\
\text { targeted therapy }\end{array}$ & [71] \\
\hline $\begin{array}{l}\text { Cutaneous } \\
\text { melanoma }\end{array}$ & PDX & AXLi (R428) & AZD7762 & $\begin{array}{l}\text { CHK1/CHK2-targeted } \\
\text { therapy }\end{array}$ & [72] \\
\hline $\begin{array}{l}\text { Cutaneous } \\
\text { melanoma; lung } \\
\text { cancer }\end{array}$ & CDX, PDX & $\begin{array}{c}(* * *) \text { AXL-107-MMAE (or } \\
\text { EnaV }\end{array}$ & $\begin{array}{l}\text { Anti-PD-1 mAb } \\
\text { (Pembrolizumab) }\end{array}$ & Immunotherapy & [73] \\
\hline Glioblastoma & $\begin{array}{l}\text { Mouse spheroid-derived } \\
\text { xenografts }\end{array}$ & AXLi (R428) & $\begin{array}{l}\text { Anti-PD-1 mAb } \\
\text { (Nivolumab) }\end{array}$ & Immunotherapy & [9] \\
\hline $\begin{array}{l}\text { Diffuse intrinsic } \\
\text { pontine glioma }\end{array}$ & PDX; mouse allografts & AXLi (R428) & Panobinostat & $\begin{array}{l}\text { Histone deacetylase } \\
\text { inhibitors }\end{array}$ & [74] \\
\hline
\end{tabular}

$\left({ }^{*}\right)$ CDX, cell lines-derived xenografts. $\left.{ }^{* *}\right)$ PDX, patient-derived xenografts. $\left({ }^{* * *}\right)$ AXL-107-MMAE, an anti-AXL antibody-drug conjugate. It represents a fusion between $\mathrm{mAb}$ and the microtubule-disrupting agent monomethyl auristatin $\mathrm{E}$. 


\subsection{Protection of Healthy Tissues from Autoimmune Damage and Immune Evasion in Cancer: Common Mechanisms}

Immune checkpoint blockade by PD-1, PD-L1 or CTLA-4 inhibitors improves survival in a proportion of patients with solid tumours. However, most of the patients do not respond to the immunotherapy or develop resistance caused by the immunosuppressive tumour microenvironment (TME). The activity of innate immune cells is required to stimulate the cytotoxic function of T lymphocytes, and insufficiency of dendritic cells may cause the failure of immune surveillance. TAM receptors, whose normal function is to limit the duration of innate immune response, mediate immune suppression in TME. Specifically, as discussed in a previous section, AXL pathway terminates TLR signaling in dendritic cells via SOCS1/3. This reduces the secretion of pro-inflammatory cytokines and counteracts tumour infiltration by T cells [36,37].

In addition to AXL function in professional phagocytes, AXL expression in tumour cells is yet another factor contributing to immunosuppression. In breast cancer cells, AXL pathway activation results in decreased expression and presentation of MHC class I antigens, leading to the decreased tumour infiltration by $\mathrm{CD} 4^{+}$and $\mathrm{CD} 8^{+} \mathrm{T}$ cells, and consequently, immune evasion $[75,76]$. In line with these findings, another important study has shown that anti-PD1 therapy-resistant melanomas expressed high levels of AXL in cancer cells [77]. Similarly, AXL signaling correlates with the elevated expression of PD-L1 in EGFR-mutant NSCLC cells [78]. In addition to driving negative feedback regulation in dendritic cells, AXL and other TAM receptors control functions of NK cells, another critical component of the innate immune system. In particular, NK cells attack and eliminate those cancer cells, which are deficient in the expression of MHC class I antigens. TAM-driven pathways downregulate the expression and function of the receptors, which operate during the differentiation and maturation of NK cells [79]. By suppressing the activity of NK cells, TAM signaling promotes metastatic spread in mouse models of malignant melanoma and breast cancer [80].

Thus, TAM receptors inhibit innate immunity leading to the reduced infiltration of $\mathrm{CD} 4^{+}$and $\mathrm{CD} 8^{+}$lymphocytes and incapacitate NK cells. Therefore, disabling TAM function sustains immunostimulatory TME, which may improve the efficacy of immune checkpoint inhibition [4]. Indeed, selective small molecule AXLi synergizes with an PD-1-blocking antibody to inhibit the growth of ovarian cancer and glioblastoma in xenograft models $[9,62]$. Moreover, another approach for combined targeting AXL and immune checkpoint has shown promise. An AXL-specific antibody-drug conjugate Enapotamabvedotin (EnaV) was generated by crosslinking anti-AXL IgG1 with auristatin E, a cytotoxic agent acting via destabilization of microtubules [71]. In xenograft melanoma and lung cancer mouse models, combined application of EnaV and anti-PD-1 therapy significantly prolonged the survival of mice as compared with single treatments [73] (Table 1).

\section{AXL, Epithelial-Mesenchymal Plasticity, Drug Tolerant Persister Cells, and Cancer Metastasis 7.1. Cancer Cells Exist in Distinct Differentiation States}

As discussed in the above sections, AXL-expressing tumour cells are endowed with invasive and drug resistant characteristics. These features are hallmarks of epithelialmesenchymal transition (EMT), an embryonic genetic program hijacked by cancer cells. EMT and the reverse process, mesenchymal-epithelial transition (MET), constitute a major source of tumour cell plasticity, and represent an important factor of cancer heterogeneity $[81,82]$. Notably, the transcription factors that regulate EMT (so-called EMT-TFs) during normal embryonic development and tumorigenesis are shared. EMT-TFs belonging to the ZEB (ZEB1 and ZEB2), SNAIL (SNAIL1 and SNAIL2/SLUG), and TWIST (TWIST1 and TWIST2) families are best-studied in the context of cancer [83,84]. EMT-TFs repress transcription of epithelial markers, and directly or indirectly activate mesenchymal genes such as vimentin. In the course of complete mesenchymal reprogramming, cells lose all epithelial characteristics, gain mesenchymal markers, mesenchymal type of cell polarity, and high invasive capabilities. It is now broadly accepted that EMT and MET are not binary 
processes, and cancer cells acquire intermediate differentiation states combining epithelial and mesenchymal features (so-called partial or hybrid EMT) $[85,86]$ (Figure 2A). These cell populations with hybrid epithelial and mesenchymal characteristics were isolated from genetically manipulated mouse models and patient-derived xenotransplants $[85,87]$. Whereas proliferative potential gradually decreases when cells progress from epithelial to a mesenchymal state, their invasive potential increases. Cells in a hybrid EMT state express EMT-TFs; they exhibit the highest tumourigenic potential and metastatic capacity. Hybrid (especially late hybrid) EMT cells are phenotypically less stable than fully differentiated epithelial or mesenchymal tumour cells. This can be explained by the fact that epithelial or mesenchymal endpoints are stabilized by self-enforcing double-negative feedbacks formed between EMT-TFs and certain miRNA species (SNAIL1-miR-34 or ZEB1/2-miR-200) [85].

A

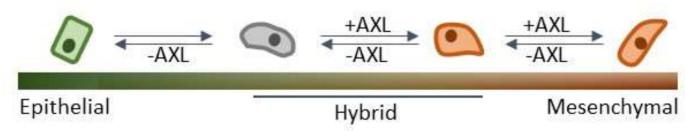

B

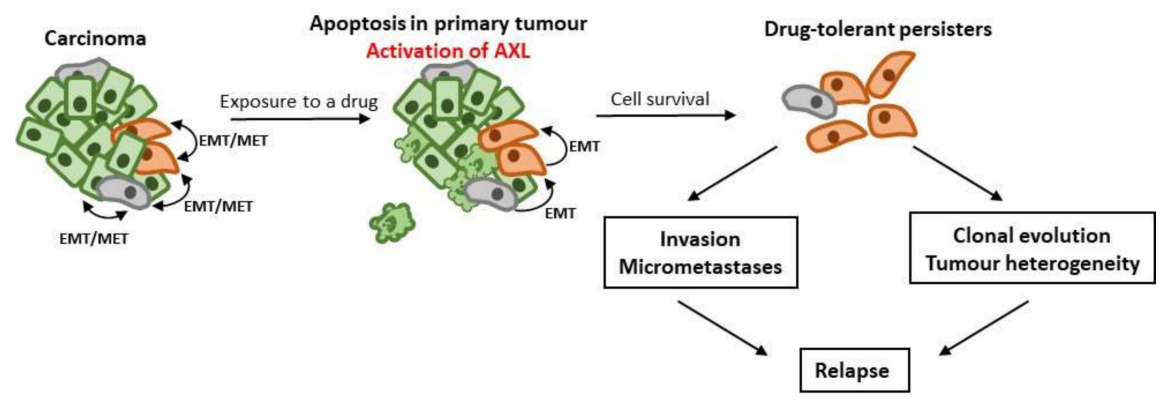

Figure 2. AXL pathway promotes drug resistance and metastasis in carcinoma. (A) Reversible EMT states of tumour cells in carcinomas. Transient activation of AXL signaling shifts the balance towards the mesenchymal end of the spectrum. (B) Therapeutic intervention results in apoptosis in a bulk of a tumour leading to PtdSer externalization and activation of AXL pathway in a proportion of tumour cells. By activating cell survival and EMT pathways, AXL stimulates the formation of invasive and drug resistant cells (drug tolerant persisters, DTPs). DTPs represent the source for the genetic evolution of cancer, cancer relapse, and spread.

\subsection{AXL Belongs to the Mesenchymal Gene Expression Signatures Characterizing Aggressive Cancers}

The association between AXL signaling and EMT has been reported in different cancer types. The expression and function of AXL are regulated at the transcriptional level by proteins implicated in epithelial-mesenchymal plasticity. $\triangle$ Np63 $\alpha$, HIF1 $\alpha$, YAP1/TEAD and FRA1/cJUN transcription factor complexes, and EMT-TF ZEB1 control AXL gene transcription directly [88-92]. At the post-transcriptional level, AXL expression is co-regulated with EMT-TFs of SNAIL family by miR-34, a p53-induced SNAIL repressor [93-95]. Transcription factors up-regulating $A X L$ transcription are parts of gene regulatory networks operating in mesenchymal and hybrid states. Whereas, miR-34 favours MET in cells with wild-type p53. Thus, AXL seems to belong to gene expression patterns favouring EMT and invasion, whose activation is promoted by mutations in TP53. In line with these considerations, AXL expression was detected in the most aggressive subtypes of bladder and ovarian cancers characterized by EMT and mutant TP53 signatures [2,26,96-98]. In breast cancer, AXL was identified as a component of the $\Delta \mathrm{Np} 63 \alpha$-driven hybrid EMT program. The resulting cells retained some epithelial traits, but were highly invasive [90]. In several reports, a driver rather than a passenger role of AXL in EMT has been demonstrated. AXL inhibition by small molecule compounds or RNA interference led to a partial MET in breast, lung, ovarian, or pancreatic carcinoma cells $[1,26,99,100]$.

Interestingly, while AXL is expressed in mouse embryos, it is implicated in cancer EMT and EMT drives critical stages of embryonic development. AXL expression is dispensable 
for embryogenesis. This peculiarity distinguishes AXL from many other RTKs, as well as most EMT inducers and effectors whose genetic ablations have more severe phenotypes and often cause embryonic lethality. The lack of embryonic abnormalities in $\mathrm{AXL}^{-/-}$mice resembles normal development of mouse embryos with depleted vimentin, a canonical EMT marker [101].

\subsection{AXL Is Implicated in Metastasis in Experimental In Vivo Models}

Consistent with the role of AXL in promoting EMT in cancer, targeting AXL by selective inhibitors, germline knockout, RNAi, and inactivating mAbs prevented etastasis of various epithelial tumours, including but not limited to, breast, lung, ovarian, and colorectal cancers. The analysis has been carried out in genetic mouse models, cell linederived xenografts (CDX), patients-derived xenografts (PDX), and in various experimental metastasis assays (summarized in Table 2).

Table 2. In vivo models demonstrate essential role of AXL in cancer metastasis.

\begin{tabular}{|c|c|c|c|}
\hline Cancer Type & Type of Study & Method of AXL Inhibition & Reference \\
\hline Breast cancer & Orthotopic model & shRNA & [102] \\
\hline Breast cancer & Intravenous metastasis assay & Anti-AXL mAb YW327.6S2 & {$[60]$} \\
\hline Breast cancer & $\begin{array}{l}\text { Orthotopic model and lung } \\
\text { metastasis assay }\end{array}$ & AXLi R428 & [103] \\
\hline Breast cancer & Lung metastasis assay & AXLi R428; shRNA & [104] \\
\hline Breast cancer & $(*) \mathrm{CDX}$ & AXLi R428; shRNA & [101] \\
\hline Breast cancer & CDX & AXLi & [105] \\
\hline Breast cancer & CDX & AXLi & [106] \\
\hline Breast cancer & Orthotopic model & CRISPR/Cas9 gene inactivation & [107] \\
\hline Triple-Negative Breast Cancer & Orthotopic model & shRNAi & [99] \\
\hline Triple-Negative Breast Cancer & CDX or $(* *)$ PDX & Anti-AXL mAb 20G7-D9 & [108] \\
\hline Triple-Negative Breast Cancer & CDX & $\begin{array}{l}\text { pan-TAM kinase inhibitor } \\
\text { BMS-777607 }\end{array}$ & [109] \\
\hline HER2 + Breast Cancer & Genetically modified mice & Germline knockout & [27] \\
\hline $\begin{array}{l}\text { Breast cancer, cutaneous } \\
\text { melanoma }\end{array}$ & CDX & Pan-TAM inhibitor LDC1267 & [80] \\
\hline Ovarian, breast, pancreatic cancer & CDX & MYD1-72 Fc decoy receptor & [110] \\
\hline Ovarian cancer & Peritoneal xenografts & $\begin{array}{l}\text { shRNA, sAXL (acts as a decoy } \\
\text { receptor) }\end{array}$ & [111] \\
\hline Ovarian cancer & Intraperitoneal injections & MYD1 Fc decoy receptor & [112] \\
\hline Ovarian cancer & CDX & AXL-aptamer & [113] \\
\hline Endometrial cancer & Orthotopic & shRNA & [114] \\
\hline Uterine cancer & CDX & siRNA & [115] \\
\hline Pancreatic cancer & CDX & Anti-AXL mAb $10 \mathrm{C} 9$ & [100] \\
\hline Colorectal cancer & $\begin{array}{l}\text { CDX (effect on dissemination in the } \\
\text { bloodstream) }\end{array}$ & Ectopic expression of AXL & [116] \\
\hline Gastric cancer & CDX & shRNA & [117] \\
\hline Clear cell renal cell carcinoma & Lung metastasis assay & shRNA, sAXL-IgG1 fusion & [91] \\
\hline NSCLC & Lung metastasis assay & shRNA & [118] \\
\hline NSCLC & Intracardiac injections & shRNA & [119] \\
\hline
\end{tabular}

$\left.{ }^{*}\right)$ CDX, cell lines-derived xenografts. $\left({ }^{* *}\right)$ PDX, patient-derived xenografts. 
Although AXL inhibition prevents metastases (Table 2), constitutive ectopic expression of AXL in metastatic breast cancer cells did not promote, but instead reduced the metastatic traits analysed in intravenous metastasis assay. In later stages of the metastatic process, the downregulation of AXL signaling was required for the interaction between cancer cells and the microenvironment in the metastatic niches, and successful metastatic colonization of the lungs [104]. Therefore, the reversibility of AXL signaling, but not persistent AXL activation facilitates metastatic dissemination. Two considerations support this conclusion. Firstly, the $A X L$ gene is rarely amplified or mutated in human cancer, which is in stark contrast to some other RTKs. Secondly, the expression of AXL is a characteristic of cells residing in the hybrid state of EMT spectrum $[90,120]$. This cell state retains the potential to regenerate fully differentiated AXL-negative cells.

\subsection{Hypothetical Role of AXL in the Formation of Drug Tolerant Persister Cancer Cells}

A dynamic equilibrium between differentiation states along the EMT/MET axis exists in most solid tumours (Figure 2A). EMT-TFs are present in cells with hybrid or mesenchymal phenotype, and activate mechanisms maintaining genome integrity, multi-drug resistance, and cell survival [121]. The survival of tumour cells with mesenchymal or hybrid characteristics upon treatment with conventional chemotherapy drugs has been demonstrated in vivo using mouse models of breast and pancreatic adenocarcinoma [122,123]. Acute exposure of cancer cells to the drugs in vitro does not lead to the eradication of the whole cell population. A small pool of viable cells, or DTPs, survive treatment and represent the source for the genetic evolution of tumours and eventually relapse [124] (Figure 2B). The presence of DTPs in the bone marrow of cancer patients after therapeutic intervention, a condition termed the minimal residual disease, indicates a high probability of cancer relapse. It has been previously hypothesized that DTP cells originate from the tumour cells residing in hybrid or mesenchymal states along the EMT/MET spectrum [125,126].

It can be speculated that AXL pathways play a decisive role in the generation and survival of DTP pools. Application of cytotoxic drugs induces apoptosis in the epithelial cells representing the bulk of the tumour, and externalization of PtdSer in the affected cells. The engagement of PtdSer with GAS6 may lead to the activation of AXL signaling in hybrid EMT/MET tumour cells (Figure 2). Within TME, GAS6 is broadly available; it is secreted by some tumour cells, cancer-associated fibroblasts (CAFs), dendritic cells, and tumour associated macrophages. Production of GAS6 is further stimulated by immunosuppressive cytokines IL10 and IFN $\alpha$, whose presence in TME is promoted by externalized PtdSer in apoptotic cells and bodies [127]. Activation of AXL signaling in hybrid EMT/MET tumour cells will have several important consequences. First, the signaling contributes to cell survival via canonical anti-apoptotic pathways leading to the formation of drugresistant DTP pools. Secondly, the activation of AXL in hybrid cells moves the EMT/MET equilibrium towards the mesenchymal end of the EMT/MET spectrum. Activation of the AXL-ELMO-DOCK180 axis and other EMT-associated signaling pathways lead to the enhanced migratory and invasive potential of DTP cells, their ability to disseminate and switch on the immune-escape mechanisms [128]. This hypothetical model explains broadly documented implication of AXL pathway in drug resistance and cancer metastasis (Table 2).

\section{Concluding Remarks}

AXL signaling has emerged as an important pathway contributing to tumour progression, metastasis, and therapy resistance. This critical role of AXL in various types of solid cancers arises from AXL function in healthy tissue. Mouse modelling and in vitro experiments demonstrated that AXL, and its relative MER, are essential for the activity of professional phagocytes in different tissues. The engulfment of dead cells during efferocytosis involves the activation of PI3K signaling, cytoskeletal reorganization via ELMO-DOCK180, and other molecular pathways implicated in cancer cell motility. The efficient clearance of apoptotic cells is an important factor of anti-inflammatory response. 
In addition, the role of AXL in immunosuppression is associated with the down-regulation of TLR signaling in dendritic cells and suppression of NK activity.

The AXL receptor is expressed both in tumour cells, which experience a complete or partial EMT, and in TME. It seems that in tumour cells, AXL signaling is activated via a mechanism similar to that operating during efferocytosis, when GAS6 ligand binds PtdSer on the membranes of dying cells and apoptotic bodies. Both these factors, GAS6 and PtdSer, are readily available in TME. GAS6 is produced by CAFs and other cells within tumour tissue, and externalized PtdSer is abundant due to stress- and cell death-causing conditions, such as oxygen radicals or hypoxia. Therapeutic interventions induce cell death in bulks of the tumours, and thereby promote AXL activation in subpopulations of AXL-expressing cells. This leads to the activation of cell survival via PI3K and EMT pathways and the formation of pools of DTP cells, which are therapy-resistant and invasive.

Another feature that specifies a broad role of AXL pathway in cancer biology is the incorporation of AXL in oncogenic signaling pathways operating in various cancers. AXL physically and functionally interacts with EGFR family members, other RTKs, and SRC family kinases among others. The consequence of this deep integration of AXL in oncogenic signaling networks is GAS6-independent activation of AXL in some cases.

Equally important for tumour biology is AXL function in dendritic and NK cells. By terminating TLR signaling in dendritic cells and suppressing NK, AXL generates an immunosuppressive environment and helps cancer cells to evade immune surveillance. The dual role of AXL in tumour and immune cells explains the reason why AXL inhibition synergizes with such a broad spectrum of therapeutic agents. The targeting of AXL moves cancer cells toward the epithelial end of EMT /MET spectrum and sensitizes them to chemo-, radio- or targeted therapies, which efficiently eradicate proliferating epithelial cells. On the other hand, AXL inactivation blocks the negative regulation of dendritic and NK cells, stimulates innate immunity, and thereby potentiates the efficacy of immune checkpoint inhibitors (Table 1). Currently, ongoing clinical trials have been aimed at identifying combinatorial therapeutic schemes which include AXL inhibition and are optimal for particular cancer types. Further research is needed to discover biomarkers that will help identify benefits to patients and evaluate tumour responses to AXL-targeted therapies.

Author Contributions: Conceptualization, E.T., M.K. and A.E.S.; data curation, A.A. and E.T.; writing-original draft preparation, A.A. and E.T.; writing—review and editing, E.T., A.E.S. and M.K.; funding acquisition, E.T. and M.K. All authors have read and agreed to the published version of the manuscript.

Funding: The research in E.T. and M.K. labs is supported by Nazarbayev University Faculty Development Research Grants (240919FD3909 to ET and 080420FD1908 to M.K.). The APC was funded by the University of Southampton.

Acknowledgments: The authors apologize to those colleagues whose relevant studies were not cited in this paper due to space limitations.

Conflicts of Interest: The authors declare no conflict of interest.

\section{References}

1. Antony, J.; Huang, R.Y. AXL-Driven EMT State as a Targetable Conduit in Cancer. Cancer Res. 2017, 77, 3725-3732. [CrossRef] [PubMed]

2. Antony, J.; Thiery, J.P.; Huang, R.Y. Epithelial-to-mesenchymal transition: Lessons from development, insights into cancer and the potential of EMT-subtype based therapeutic intervention. Phys. Biol. 2019, 16, 041004. [CrossRef] [PubMed]

3. Colavito, S.A. AXL as a Target in Breast Cancer Therapy. J. Oncol. 2020, 2020, 5291952. [CrossRef]

4. Aehnlich, P.; Powell, R.M.; Peeters, M.J.W.; Rahbech, A.; Thor Straten, P. TAM Receptor Inhibition-Implications for Cancer and the Immune System. Cancers 2021, 13, 1195. [CrossRef]

5. Caberoy, N.B.; Alvarado, G.; Bigcas, J.L.; Li, W. Galectin-3 is a new MerTK-specific eat-me signal. J. Cell Physiol. 2012, 227, 401-407. [CrossRef]

6. Caberoy, N.B.; Zhou, Y.; Li, W. Tubby and tubby-like protein 1 are new MerTK ligands for phagocytosis. EMBO J. 2010, 29, 3898-3910. [CrossRef] 
7. Nomura, K.; Vilalta, A.; Allendorf, D.H.; Hornik, T.C.; Brown, G.C. Activated Microglia Desialylate and Phagocytose Cells via Neuraminidase, Galectin-3, and Mer Tyrosine Kinase. J. Immunol. 2017, 198, 4792-4801. [CrossRef]

8. Lew, E.D.; Oh, J.; Burrola, P.G.; Lax, I.; Zagórska, A.; Través, P.G.; Schlessinger, J.; Lemke, G. Differential TAM receptor-ligandphospholipid interactions delimit differential TAM bioactivities. eLife 2014, 3, e03385. [CrossRef]

9. Sadahiro, H.; Kang, K.D.; Gibson, J.T.; Minata, M.; Yu, H.; Shi, J.; Chhipa, R.; Chen, Z.; Lu, S.; Simoni, Y.; et al. Activation of the Receptor Tyrosine Kinase AXL Regulates the Immune Microenvironment in Glioblastoma. Cancer Res. 2018, 78, $3002-3013$. [CrossRef]

10. Lu, Y.; Wan, J.; Yang, Z.; Lei, X.; Niu, Q.; Jiang, L.; Passtoors, W.M.; Zang, A.; Fraering, P.C.; Wu, F. Regulated intramembrane proteolysis of the AXL receptor kinase generates an intracellular domain that localizes in the nucleus of cancer cells. FASEB $J$. 2017, 31, 1382-1397. [CrossRef] [PubMed]

11. Merilahti, J.A.M.; Ojala, V.K.; Knittle, A.M.; Pulliainen, A.T.; Elenius, K. Genome-wide screen of gamma-secretase-mediated intramembrane cleavage of receptor tyrosine kinases. Mol. Biol. Cell 2017, 28, 3123-3131. [CrossRef]

12. Brand, T.M.; Iida, M.; Corrigan, K.L.; Braverman, C.M.; Coan, J.P.; Flanigan, B.G.; Stein, A.P.; Salgia, R.; Rolff, J.; Kimple, R.J.; et al. The receptor tyrosine kinase AXL mediates nuclear translocation of the epidermal growth factor receptor. Sci. Signal. 2017, 10, eaag1064. [CrossRef]

13. Ammoun, S.; Provenzano, L.; Zhou, L.; Barczyk, M.; Evans, K.; Hilton, D.A.; Hafizi, S.; Hanemann, C.O. Axl/Gas6/NFkB signalling in schwannoma pathological proliferation, adhesion and survival. Oncogene 2014, 33, 336-346. [CrossRef]

14. Flem-Karlsen, K.; Nyakas, M.; Farstad, I.N.; McFadden, E.; Wernhoff, P.; Jacobsen, K.D.; Flørenes, V.A.; Mælandsmo, G.M. Soluble AXL as a marker of disease progression and survival in melanoma. PLoS ONE 2020, 15, e0227187. [CrossRef]

15. Song, W.; Wang, H.; Lu, M.; Ni, X.; Bahri, N.; Zhu, S.; Chen, L.; Wu, Y.; Qiu, J.; Fletcher, J.A.; et al. AXL Inactivation Inhibits Mesothelioma Growth and Migration via Regulation of p53 Expression. Cancers 2020, 12, 2757. [CrossRef]

16. Dantas-Barbosa, C.; Lesluyes, T.; Loarer, F.L.; Chibon, F.; Treilleux, I.; Coindre, J.M.; Meeus, P.; Brahmi, M.; Bally, O.; Ray-Coquard, I.; et al. Expression and role of TYRO3 and AXL as potential therapeutical targets in leiomyosarcoma. Br. J. Cancer 2017, 117, 1787-1797. [CrossRef] [PubMed]

17. Migdall-Wilson, J.; Bates, C.; Schlegel, J.; Brandão, L.; Linger, R.M.; DeRyckere, D.; Graham, D.K. Prolonged exposure to a Mer ligand in leukemia: Gas6 favors expression of a partial Mer glycoform and reveals a novel role for Mer in the nucleus. PLoS ONE 2012, 7, e31635. [CrossRef] [PubMed]

18. Sasaki, T.; Knyazev, P.G.; Clout, N.J.; Cheburkin, Y.; Göhring, W.; Ullrich, A.; Timpl, R.; Hohenester, E. Structural basis for Gas6-Axl signalling. EMBO J. 2006, 25, 80-87. [CrossRef] [PubMed]

19. Braunger, J.; Schleithoff, L.; Schulz, A.S.; Kessler, H.; Lammers, R.; Ullrich, A.; Bartram, C.R.; Janssen, J.W. Intracellular signaling of the Ufo/Axl receptor tyrosine kinase is mediated mainly by a multi-substrate docking-site. Oncogene 1997, 14, 2619-2631. [CrossRef]

20. Ling, L.; Templeton, D.; Kung, H.J. Identification of the major autophosphorylation sites of Nyk/Mer, an NCAM-related receptor tyrosine kinase. J. Biol. Chem. 1996, 271, 18355-18362. [CrossRef] [PubMed]

21. Brown, J.E.; Krodel, M.; Pazos, M.; Lai, C.; Prieto, A.L. Cross-phosphorylation, signaling and proliferative functions of the Tyro3 and Axl receptors in Rat2 cells. PLoS ONE 2012, 7, e36800. [CrossRef]

22. Vouri, M.; An, Q.; Pilkington, G.; Hafizi, S. 107-Hetero-interaction amongst Tyro3 and Axl receptor tyrosine kinases diversifies cancer signalling. Eur. J. Cancer 2016, 69, S42. [CrossRef]

23. Gusenbauer, S.; Vlaicu, P.; Ullrich, A. HGF induces novel EGFR functions involved in resistance formation to tyrosine kinase inhibitors. Oncogene 2013, 32, 3846-3856. [CrossRef]

24. Meyer, A.S.; Miller, M.A.; Gertler, F.B.; Lauffenburger, D.A. The receptor AXL diversifies EGFR signaling and limits the response to EGFR-targeted inhibitors in triple-negative breast cancer cells. Sci. Signal. 2013, 6, ra66. [CrossRef]

25. Elkabets, M.; Pazarentzos, E.; Juric, D.; Sheng, Q.; Pelossof, R.A.; Brook, S.; Benzaken, A.O.; Rodon, J.; Morse, N.; Yan, J.J.; et al. AXL mediates resistance to PI3K $\alpha$ inhibition by activating the EGFR/PKC/mTOR axis in head and neck and esophageal squamous cell carcinomas. Cancer Cell 2015, 27, 533-546. [CrossRef]

26. Antony, J.; Tan, T.Z.; Kelly, Z.; Low, J.; Choolani, M.; Recchi, C.; Gabra, H.; Thiery, J.P.; Huang, R.Y. The GAS6-AXL signaling network is a mesenchymal (Mes) molecular subtype-specific therapeutic target for ovarian cancer. Sci. Signal. 2016, 9, ra97. [CrossRef] [PubMed]

27. Goyette, M.A.; Duhamel, S.; Aubert, L.; Pelletier, A.; Savage, P.; Thibault, M.P.; Johnson, R.M.; Carmeliet, P.; Basik, M.; Gaboury, L.; et al. The Receptor Tyrosine Kinase AXL Is Required at Multiple Steps of the Metastatic Cascade during HER2-Positive Breast Cancer Progression. Cell Rep. 2018, 23, 1476-1490. [CrossRef]

28. Ruan, G.X.; Kazlauskas, A. Axl is essential for VEGF-A-dependent activation of PI3K/Akt. EMBO J. 2012, $31,1692-1703$. [CrossRef] [PubMed]

29. Lu, Q.; Gore, M.; Zhang, Q.; Camenisch, T.; Boast, S.; Casagranda, F.; Lai, C.; Skinner, M.K.; Klein, R.; Matsushima, G.K.; et al. Tyro-3 family receptors are essential regulators of mammalian spermatogenesis. Nature 1999, 398, 723-728. [CrossRef] [PubMed]

30. Lu, Q.; Lemke, G. Homeostatic regulation of the immune system by receptor tyrosine kinases of the Tyro 3 family. Science 2001, 293, 306-311. [CrossRef] [PubMed]

31. Linger, R.M.; Keating, A.K.; Earp, H.S.; Graham, D.K. TAM receptor tyrosine kinases: Biologic functions, signaling, and potential therapeutic targeting in human cancer. Adv. Cancer Res. 2008, 100, 35-83. [CrossRef] [PubMed] 
32. Lemke, G.; Burstyn-Cohen, T. TAM receptors and the clearance of apoptotic cells. Ann. N. Y. Acad. Sci. 2010, 1209, 23-29. [CrossRef]

33. Gallucci, S.; Matzinger, P. Danger signals: SOS to the immune system. Curr. Opin. Immunol. 2001, 13, 114-119. [CrossRef]

34. Lemke, G. Biology of the TAM receptors. Cold Spring Harb. Perspect. Biol. 2013, 5, a009076. [CrossRef]

35. Burstyn-Cohen, T.; Lew, E.D.; Través, P.G.; Burrola, P.G.; Hash, J.C.; Lemke, G. Genetic dissection of TAM receptor-ligand interaction in retinal pigment epithelial cell phagocytosis. Neuron 2012, 76, 1123-1132. [CrossRef] [PubMed]

36. Seitz, H.M.; Camenisch, T.D.; Lemke, G.; Earp, H.S.; Matsushima, G.K. Macrophages and dendritic cells use different Axl/Mertk/Tyro3 receptors in clearance of apoptotic cells. J. Immunol. 2007, 178, 5635-5642. [CrossRef]

37. Balasubramanian, K.; Schroit, A.J. Aminophospholipid asymmetry: A matter of life and death. Annu. Rev. Physiol. 2003, 65, 701-734. [CrossRef]

38. Park, S.Y.; Kim, I.S. Engulfment signals and the phagocytic machinery for apoptotic cell clearance. Exp. Mol. Med. 2017, 49, e331. [CrossRef]

39. Nakaya, M.; Tanaka, M.; Okabe, Y.; Hanayama, R.; Nagata, S. Opposite effects of rho family GTPases on engulfment of apoptotic cells by macrophages. J. Biol. Chem. 2006, 281, 8836-8842. [CrossRef]

40. Côté, J.F.; Vuori, K. GEF what? Dock180 and related proteins help Rac to polarize cells in new ways. Trends Cell Biol. 2007, 17, 383-393. [CrossRef]

41. Liau, N.P.D.; Laktyushin, A.; Lucet, I.S.; Murphy, J.M.; Yao, S.; Whitlock, E.; Callaghan, K.; Nicola, N.A.; Kershaw, N.J.; Babon, J.J. The molecular basis of JAK/STAT inhibition by SOCS1. Nat. Commun. 2018, 9, 1558. [CrossRef]

42. Rothlin, C.V.; Lemke, G. TAM receptor signaling and autoimmune disease. Curr. Opin. Immunol. 2010, 22, 740-746. [CrossRef]

43. Yamazaki, M.; Maruyama, S.; Abé, T.; Tsuneki, M.; Kato, H.; Izumi, K.; Tanuma, J.I.; Cheng, J.; Saku, T. Rac1-dependent phagocytosis of apoptotic cells by oral squamous cell carcinoma cells: A possible driving force for tumor progression. Exp. Cell Res. 2020, 392, 112013. [CrossRef]

44. Nguyen, K.Q.; Tsou, W.I.; Calarese, D.A.; Kimani, S.G.; Singh, S.; Hsieh, S.; Liu, Y.; Lu, B.; Wu, Y.; Garforth, S.J.; et al. Overexpression of MERTK receptor tyrosine kinase in epithelial cancer cells drives efferocytosis in a gain-of-function capacity. $J$. Biol. Chem. 2014, 289, 25737-25749. [CrossRef]

45. Koren, E.; Fuchs, Y. Modes of Regulated Cell Death in Cancer. Cancer Discov. 2021, 11, 245-265. [CrossRef] [PubMed]

46. Abu-Thuraia, A.; Gauthier, R.; Chidiac, R.; Fukui, Y.; Screaton, R.A.; Gratton, J.P.; Côté, J.F. Axl phosphorylates Elmo scaffold proteins to promote Rac activation and cell invasion. Mol. Cell Biol. 2015, 35, 76-87. [CrossRef] [PubMed]

47. Li, W.; Xiong, X.; Abdalla, A.; Alejo, S.; Zhu, L.; Lu, F.; Sun, H. HGF-induced formation of the MET-AXL-ELMO2-DOCK180 complex promotes RAC1 activation, receptor clustering, and cancer cell migration and invasion. J. Biol. Chem. 2018, 293, 15397-15418. [CrossRef] [PubMed]

48. Zhu, C.; Wei, Y.; Wei, X. AXL receptor tyrosine kinase as a promising anti-cancer approach: Functions, molecular mechanisms and clinical applications. Mol. Cancer 2019, 18, 153. [CrossRef]

49. Xu, J.; Jia, L.; Ma, H.; Li, Y.; Ma, Z.; Zhao, Y. Axl gene knockdown inhibits the metastasis properties of hepatocellular carcinoma via PI3K/Akt-PAK1 signal pathway. Tumour Biol. 2014, 35, 3809-3817. [CrossRef]

50. Abu-Thuraia, A.; Goyette, M.A.; Boulais, J.; Delliaux, C.; Apcher, C.; Schott, C.; Chidiac, R.; Bagci, H.; Thibault, M.P.; Davidson, D.; et al. AXL confers cell migration and invasion by hijacking a PEAK1-regulated focal adhesion protein network. Nat. Commun. 2020, 11, 3586. [CrossRef]

51. Gao, Y.; Qin, Y.; Wan, C.; Sun, Y.; Meng, J.; Huang, J.; Hu, Y.; Jin, H.; Yang, K. Small Extracellular Vesicles: A Novel Avenue for Cancer Management. Front. Oncol. 2021, 11, 638357. [CrossRef]

52. Matsumura, S.; Minamisawa, T.; Suga, K.; Kishita, H.; Akagi, T.; Ichiki, T.; Ichikawa, Y.; Shiba, K. Subtypes of tumour cell-derived small extracellular vesicles having differently externalized phosphatidylserine. J. Extracell. Vesicles 2019, 8, 1579541. [CrossRef] [PubMed]

53. Graham, D.K.; DeRyckere, D.; Davies, K.D.; Earp, H.S. The TAM family: Phosphatidylserine sensing receptor tyrosine kinases gone awry in cancer. Nat. Rev. Cancer 2014, 14, 769-785. [CrossRef] [PubMed]

54. Park, M.; Kim, J.W.; Kim, K.M.; Kang, S.; Kim, W.; Kim, J.K.; Cho, Y.; Lee, H.; Baek, M.C.; Bae, J.H.; et al. Circulating Small Extracellular Vesicles Activate TYRO3 to Drive Cancer Metastasis and Chemoresistance. Cancer Res. 2021, 81, 3539-3553. [CrossRef] [PubMed]

55. Ekman, C.; Stenhoff, J.; Dahlbäck, B. Gas6 is complexed to the soluble tyrosine kinase receptor Axl in human blood. J. Thromb. Haemost. 2010, 8, 838-844. [CrossRef]

56. Kanzaki, R.; Naito, H.; Kise, K.; Takara, K.; Eino, D.; Minami, M.; Shintani, Y.; Funaki, S.; Kawamura, T.; Kimura, T.; et al. Gas6 derived from cancer-associated fibroblasts promotes migration of Axl-expressing lung cancer cells during chemotherapy. Sci. Rep. 2017, 7, 10613. [CrossRef]

57. Wu, G.; Ma, Z.; Cheng, Y.; Hu, W.; Deng, C.; Jiang, S.; Li, T.; Chen, F.; Yang, Y. Targeting Gas6/TAM in cancer cells and tumor microenvironment. Mol. Cancer 2018, 17, 20. [CrossRef]

58. Myers, S.H.; Brunton, V.G.; Unciti-Broceta, A. AXL Inhibitors in Cancer: A Medicinal Chemistry Perspective. J. Med. Chem. 2016, 59, 3593-3608. [CrossRef] 
59. Wium, M.; Ajayi-Smith, A.F.; Paccez, J.D.; Zerbini, L.F. The Role of the Receptor Tyrosine Kinase Axl in Carcinogenesis and Development of Therapeutic Resistance: An Overview of Molecular Mechanisms and Future Applications. Cancers 2021, $13,1521$. [CrossRef]

60. Ye, X.; Li, Y.; Stawicki, S.; Couto, S.; Eastham-Anderson, J.; Kallop, D.; Weimer, R.; Wu, Y.; Pei, L. An anti-Axl monoclonal antibody attenuates xenograft tumor growth and enhances the effect of multiple anticancer therapies. Oncogene 2010, 29, 5254-5264. [CrossRef] [PubMed]

61. Wang, C.; Jin, H.; Wang, N.; Fan, S.; Wang, Y.; Zhang, Y.; Wei, L.; Tao, X.; Gu, D.; Zhao, F.; et al. Gas6/Axl Axis Contributes to Chemoresistance and Metastasis in Breast Cancer through Akt/GSK-3 $\beta$ / $\beta$-catenin Signaling. Theranostics 2016, 6, 1205-1219. [CrossRef] [PubMed]

62. Guo, Z.; Li, Y.; Zhang, D.; Ma, J. Axl inhibition induces the antitumor immune response which can be further potentiated by PD-1 blockade in the mouse cancer models. Oncotarget 2017, 8, 89761-89774. [CrossRef] [PubMed]

63. Zhang, Z.; Lee, J.C.; Lin, L.; Olivas, V.; Au, V.; LaFramboise, T.; Abdel-Rahman, M.; Wang, X.; Levine, A.D.; Rho, J.K.; et al. Activation of the AXL kinase causes resistance to EGFR-targeted therapy in lung cancer. Nat. Genet. 2012, 44, 852-860. [CrossRef]

64. Sen, T.; Tong, P.; Diao, L.; Li, L.; Fan, Y.; Hoff, J.; Heymach, J.V.; Wang, J.; Byers, L.A. Targeting AXL and mTOR Pathway Overcomes Primary and Acquired Resistance to WEE1 Inhibition in Small-Cell Lung Cancer. Clin. Cancer Res. 2017, 23, 6239-6253. [CrossRef]

65. Du, W.; Huang, H.; Sorrelle, N.; Brekken, R.A. Sitravatinib potentiates immune checkpoint blockade in refractory cancer models. JCI Insight 2018, 3, e124184. [CrossRef] [PubMed]

66. Taniguchi, H.; Yamada, T.; Wang, R.; Tanimura, K.; Adachi, Y.; Nishiyama, A.; Tanimoto, A.; Takeuchi, S.; Araujo, L.H.; Boroni, M.; et al. AXL confers intrinsic resistance to osimertinib and advances the emergence of tolerant cells. Nat. Commun. 2019, 10, 259. [CrossRef]

67. Okura, N.; Nishioka, N.; Yamada, T.; Taniguchi, H.; Tanimura, K.; Katayama, Y.; Yoshimura, A.; Watanabe, S.; Kikuchi, T.; Shiotsu, S.; et al. ONO-7475, a Novel AXL Inhibitor, Suppresses the Adaptive Resistance to Initial EGFR-TKI Treatment in. Clin. Cancer Res. 2020, 26, 2244-2256. [CrossRef]

68. Hong, J.; Maacha, S.; Belkhiri, A. Transcriptional upregulation of c-MYC by AXL confers epirubicin resistance in esophageal adenocarcinoma. Mol. Oncol. 2018, 12, 2191-2208. [CrossRef]

69. Ludwig, K.F.; Du, W.; Sorrelle, N.B.; Wnuk-Lipinska, K.; Topalovski, M.; Toombs, J.E.; Cruz, V.H.; Yabuuchi, S.; Rajeshkumar, N.V.; Maitra, A.; et al. Small-Molecule Inhibition of Axl Targets Tumor Immune Suppression and Enhances Chemotherapy in Pancreatic Cancer. Cancer Res. 2018, 78, 246-255. [CrossRef]

70. McDaniel, N.K.; Iida, M.; Nickel, K.P.; Longhurst, C.A.; Fischbach, S.R.; Rodems, T.S.; Kranjac, C.A.; Bo, A.Y.; Luo, Q.; Gallagher, M.M.; et al. AXL Mediates Cetuximab and Radiation Resistance Through Tyrosine 821 and the c-ABL Kinase Pathway in Head and Neck Cancer. Clin. Cancer Res. 2020, 26, 4349-4359. [CrossRef]

71. Boshuizen, J.; Koopman, L.A.; Krijgsman, O.; Shahrabi, A.; van den Heuvel, E.G.; Ligtenberg, M.A.; Vredevoogd, D.W.; Kemper, K.; Kuilman, T.; Song, J.Y.; et al. Cooperative targeting of melanoma heterogeneity with an AXL antibody-drug conjugate and BRAF/MEK inhibitors. Nat. Med. 2018, 24, 203-212. [CrossRef] [PubMed]

72. Flem-Karlsen, K.; McFadden, E.; Omar, N.; Haugen, M.H.; Øy, G.F.; Ryder, T.; Gullestad, H.P.; Hermann, R.; Mælandsmo, G.M.; Flørenes, V.A. Targeting AXL and the DNA Damage Response Pathway as a Novel Therapeutic Strategy in Melanoma. Mol. Cancer Ther. 2020, 19, 895-905. [CrossRef] [PubMed]

73. Boshuizen, J.; Pencheva, N.; Krijgsman, O.; Altimari, D.D.; Castro, P.G.; de Bruijn, B.; Ligtenberg, M.A.; Gresnigt-Van den Heuvel, E.; Vredevoogd, D.W.; Song, J.Y.; et al. Cooperative Targeting of Immunotherapy-Resistant Melanoma and Lung Cancer by an AXL-Targeting Antibody-Drug Conjugate and Immune Checkpoint Blockade. Cancer Res. 2021, 81, 1775-1787. [CrossRef] [PubMed]

74. Meel, M.H.; de Gooijer, M.C.; Metselaar, D.S.; Sewing, A.C.P.; Zwaan, K.; Waranecki, P.; Breur, M.; Buil, L.C.M.; Lagerweij, T.; Wedekind, L.E.; et al. Combined Therapy of AXL and HDAC Inhibition Reverses Mesenchymal Transition in Diffuse Intrinsic Pontine Glioma. Clin. Cancer Res. 2020, 26, 3319-3332. [CrossRef] [PubMed]

75. Aguilera, T.A.; Giaccia, A.J. Molecular Pathways: Oncologic Pathways and Their Role in T-cell Exclusion and Immune Evasion-A New Role for the AXL Receptor Tyrosine Kinase. Clin. Cancer Res. 2017, 23, 2928-2933. [CrossRef] [PubMed]

76. Aguilera, T.A.; Rafat, M.; Castellini, L.; Shehade, H.; Kariolis, M.S.; Hui, A.B.; Stehr, H.; von Eyben, R.; Jiang, D.; Ellies, L.G.; et al. Reprogramming the immunological microenvironment through radiation and targeting Axl. Nat. Commun. 2016, 7, 13898. [CrossRef]

77. Hugo, W.; Zaretsky, J.M.; Sun, L.; Song, C.; Moreno, B.H.; Hu-Lieskovan, S.; Berent-Maoz, B.; Pang, J.; Chmielowski, B.; Cherry, G.; et al. Genomic and Transcriptomic Features of Response to Anti-PD-1 Therapy in Metastatic Melanoma. Cell 2016, 165, 35-44. [CrossRef]

78. Tsukita, Y.; Fujino, N.; Miyauchi, E.; Saito, R.; Fujishima, F.; Itakura, K.; Kyogoku, Y.; Okutomo, K.; Yamada, M.; Okazaki, T.; et al. Axl kinase drives immune checkpoint and chemokine signalling pathways in lung adenocarcinomas. Mol. Cancer 2019, 18, 24. [CrossRef]

79. Akalu, Y.T.; Rothlin, C.V.; Ghosh, S. TAM receptor tyrosine kinases as emerging targets of innate immune checkpoint blockade for cancer therapy. Immunol. Rev. 2017, 276, 165-177. [CrossRef] 
80. Paolino, M.; Choidas, A.; Wallner, S.; Pranjic, B.; Uribesalgo, I.; Loeser, S.; Jamieson, A.M.; Langdon, W.Y.; Ikeda, F.; Fededa, J.P.; et al. The E3 ligase Cbl-b and TAM receptors regulate cancer metastasis via natural killer cells. Nature 2014, 507, 508-512. [CrossRef]

81. Nieto, M.A. Epithelial plasticity: A common theme in embryonic and cancer cells. Science 2013, 342, 1234850. [CrossRef] [PubMed]

82. Dhillon, A.S.; Tulchinsky, E. FRA-1 as a driver of tumour heterogeneity: A nexus between oncogenes and embryonic signalling pathways in cancer. Oncogene 2015, 34, 4421-4428. [CrossRef] [PubMed]

83. Stemmler, M.P.; Eccles, R.L.; Brabletz, S.; Brabletz, T. Non-redundant functions of EMT transcription factors. Nat. Cell Biol. 2019, 21, 102-112. [CrossRef] [PubMed]

84. Derynck, R.; Weinberg, R.A. EMT and Cancer: More Than Meets the Eye. Dev. Cell 2019, 49, 313-316. [CrossRef]

85. Pastushenko, I.; Blanpain, C. EMT Transition States during Tumor Progression and Metastasis. Trends Cell Biol. 2019, 29, 212-226. [CrossRef]

86. Bakir, B.; Chiarella, A.M.; Pitarresi, J.R.; Rustgi, A.K. EMT, MET, Plasticity, and Tumor Metastasis. Trends Cell Biol. 2020, 30, 764-776. [CrossRef]

87. Pastushenko, I.; Mauri, F.; Song, Y.; de Cock, F.; Meeusen, B.; Swedlund, B.; Impens, F.; Van Haver, D.; Opitz, M.; Thery, M.; et al. Fat1 deletion promotes hybrid EMT state, tumour stemness and metastasis. Nature 2021, 589, 448-455. [CrossRef]

88. Xu, M.Z.; Chan, S.W.; Liu, A.M.; Wong, K.F.; Fan, S.T.; Chen, J.; Poon, R.T.; Zender, L.; Lowe, S.W.; Hong, W.; et al. AXL receptor kinase is a mediator of YAP-dependent oncogenic functions in hepatocellular carcinoma. Oncogene 2011, 30, 1229-1240. [CrossRef]

89. Sayan, A.E.; Stanford, R.; Vickery, R.; Grigorenko, E.; Diesch, J.; Kulbicki, K.; Edwards, R.; Pal, R.; Greaves, P.; Jariel-Encontre, I.; et al. Fra-1 controls motility of bladder cancer cells via transcriptional upregulation of the receptor tyrosine kinase AXL. Oncogene 2012, 31, 1493-1503. [CrossRef]

90. Dang, T.T.; Esparza, M.A.; Maine, E.A.; Westcott, J.M.; Pearson, G.W. $\Delta$ Np63 $\alpha$ Promotes Breast Cancer Cell Motility through the Selective Activation of Components of the Epithelial-to-Mesenchymal Transition Program. Cancer Res. 2015, 75, 3925-3935. [CrossRef]

91. Rankin, E.B.; Fuh, K.C.; Castellini, L.; Viswanathan, K.; Finger, E.C.; Diep, A.N.; LaGory, E.L.; Kariolis, M.S.; Chan, A.; Lindgren, D.; et al. Direct regulation of GAS6/AXL signaling by HIF promotes renal metastasis through SRC and MET. Proc. Natl. Acad. Sci. USA 2014, 111, 13373-13378. [CrossRef] [PubMed]

92. Lehmann, W.; Mossmann, D.; Kleemann, J.; Mock, K.; Meisinger, C.; Brummer, T.; Herr, R.; Brabletz, S.; Stemmler, M.P.; Brabletz, T. ZEB1 turns into a transcriptional activator by interacting with YAP1 in aggressive cancer types. Nat. Commun. 2016, 7, 10498. [CrossRef] [PubMed]

93. Siemens, H.; Jackstadt, R.; Hünten, S.; Kaller, M.; Menssen, A.; Götz, U.; Hermeking, H. miR-34 and SNAIL form a double-negative feedback loop to regulate epithelial-mesenchymal transitions. Cell Cycle 2011, 10, 4256-4271. [CrossRef] [PubMed]

94. Mackiewicz, M.; Huppi, K.; Pitt, J.J.; Dorsey, T.H.; Ambs, S.; Caplen, N.J. Identification of the receptor tyrosine kinase AXL in breast cancer as a target for the human miR-34a microRNA. Breast Cancer Res. Treat. 2011, 130, 663-679. [CrossRef]

95. Mudduluru, G.; Ceppi, P.; Kumarswamy, R.; Scagliotti, G.V.; Papotti, M.; Allgayer, H. Regulation of Axl receptor tyrosine kinase expression by miR-34a and miR-199a/b in solid cancer. Oncogene 2011, 30, 2888-2899. [CrossRef]

96. Choi, W.; Porten, S.; Kim, S.; Willis, D.; Plimack, E.R.; Hoffman-Censits, J.; Roth, B.; Cheng, T.; Tran, M.; Lee, I.L.; et al. Identification of distinct basal and luminal subtypes of muscle-invasive bladder cancer with different sensitivities to frontline chemotherapy. Cancer Cell 2014, 25, 152-165. [CrossRef]

97. Tan, T.Z.; Miow, Q.H.; Huang, R.Y.; Wong, M.K.; Ye, J.; Lau, J.A.; Wu, M.C.; Bin Abdul Hadi, L.H.; Soong, R.; Choolani, M.; et al. Functional genomics identifies five distinct molecular subtypes with clinical relevance and pathways for growth control in epithelial ovarian cancer. EMBO Mol. Med. 2013, 5, 1051-1066. [CrossRef]

98. Tan, T.Z.; Rouanne, M.; Tan, K.T.; Huang, R.Y.; Thiery, J.P. Molecular Subtypes of Urothelial Bladder Cancer: Results from a Meta-cohort Analysis of 2411 Tumors. Eur. Urol. 2019, 75, 423-432. [CrossRef]

99. Gjerdrum, C.; Tiron, C.; Høiby, T.; Stefansson, I.; Haugen, H.; Sandal, T.; Collett, K.; Li, S.; McCormack, E.; Gjertsen, B.T.; et al. Axl is an essential epithelial-to-mesenchymal transition-induced regulator of breast cancer metastasis and patient survival. Proc. Natl. Acad. Sci. USA 2010, 107, 1124-1129. [CrossRef]

100. Kirane, A.; Ludwig, K.F.; Sorrelle, N.; Haaland, G.; Sandal, T.; Ranaweera, R.; Toombs, J.E.; Wang, M.; Dineen, S.P.; Micklem, D.; et al. Warfarin Blocks Gas6-Mediated Axl Activation Required for Pancreatic Cancer Epithelial Plasticity and Metastasis. Cancer Res. 2015, 75, 3699-3705. [CrossRef]

101. Colucci-Guyon, E.; Portier, M.M.; Dunia, I.; Paulin, D.; Pournin, S.; Babinet, C. Mice lacking vimentin develop and reproduce without an obvious phenotype. Cell 1994, 79, 679-694. [CrossRef]

102. Li, Y.; Ye, X.; Tan, C.; Hongo, J.A.; Zha, J.; Liu, J.; Kallop, D.; Ludlam, M.J.; Pei, L. Axl as a potential therapeutic target in cancer: Role of Axl in tumor growth, metastasis and angiogenesis. Oncogene 2009, 28, 3442-3455. [CrossRef]

103. Holland, S.J.; Pan, A.; Franci, C.; Hu, Y.; Chang, B.; Li, W.; Duan, M.; Torneros, A.; Yu, J.; Heckrodt, T.J.; et al. R428, a selective small molecule inhibitor of Axl kinase, blocks tumor spread and prolongs survival in models of metastatic breast cancer. Cancer Res. 2010, 70, 1544-1554. [CrossRef]

104. Del Pozo Martin, Y.; Park, D.; Ramachandran, A.; Ombrato, L.; Calvo, F.; Chakravarty, P.; Spencer-Dene, B.; Derzsi, S.; Hill, C.S.; Sahai, E.; et al. Mesenchymal Cancer Cell-Stroma Crosstalk Promotes Niche Activation, Epithelial Reversion, and Metastatic Colonization. Cell Rep. 2015, 13, 2456-2469. [CrossRef] [PubMed] 
105. Tan, L.; Zhang, Z.; Gao, D.; Luo, J.; Tu, Z.C.; Li, Z.; Peng, L.; Ren, X.; Ding, K. 4-Oxo-1,4-dihydroquinoline-3-carboxamide Derivatives as New Axl Kinase Inhibitors. J. Med. Chem. 2016, 59, 6807-6825. [CrossRef] [PubMed]

106. Szabadkai, I.; Torka, R.; Garamvölgyi, R.; Baska, F.; Gyulavári, P.; Boros, S.; Illyés, E.; Choidas, A.; Ullrich, A.; Örfi, L. Discovery of N-[4-(Quinolin-4-yloxy)phenyl]benzenesulfonamides as Novel AXL Kinase Inhibitors. J. Med. Chem. 2018, 61, 6277-6292. [CrossRef] [PubMed]

107. Davra, V.; Kumar, S.; Geng, K.; Calianese, D.; Mehta, D.; Gadiyar, V.; Kasikara, C.; Lahey, K.C.; Chang, Y.J.; Wichroski, M.; et al. Axl and Mertk Receptors Cooperate to Promote Breast Cancer Progression by Combined Oncogenic Signaling and Evasion of Host Antitumor Immunity. Cancer Res. 2021, 81, 698-712. [CrossRef] [PubMed]

108. Leconet, W.; Chentouf, M.; du Manoir, S.; Chevalier, C.; Sirvent, A.; Aït-Arsa, I.; Busson, M.; Jarlier, M.; Radosevic-Robin, N.; Theillet, C.; et al. Therapeutic Activity of Anti-AXL Antibody against Triple-Negative Breast Cancer Patient-Derived Xenografts and Metastasis. Clin. Cancer Res. 2017, 23, 2806-2816. [CrossRef]

109. Kasikara, C.; Davra, V.; Calianese, D.; Geng, K.; Spires, T.E.; Quigley, M.; Wichroski, M.; Sriram, G.; Suarez-Lopez, L.; Yaffe, M.B.; et al. Pan-TAM Tyrosine Kinase Inhibitor BMS-777607 Enhances Anti-PD-1 mAb Efficacy in a Murine Model of Triple-Negative Breast Cancer. Cancer Res. 2019, 79, 2669-2683. [CrossRef]

110. Kariolis, M.S.; Miao, Y.R.; Diep, A.; Nash, S.E.; Olcina, M.M.; Jiang, D.; Jones, D.S.; Kapur, S.; Mathews, I.I.; Koong, A.C.; et al. Inhibition of the GAS6/AXL pathway augments the efficacy of chemotherapies. J. Clin. Investig. 2017, 127, 183-198. [CrossRef]

111. Rankin, E.B.; Fuh, K.C.; Taylor, T.E.; Krieg, A.J.; Musser, M.; Yuan, J.; Wei, K.; Kuo, C.J.; Longacre, T.A.; Giaccia, A.J. AXL is an essential factor and therapeutic target for metastatic ovarian cancer. Cancer Res. 2010, 70, 7570-7579. [CrossRef]

112. Kariolis, M.S.; Miao, Y.R.; Jones, D.S.; Kapur, S.; Mathews, I.I.; Giaccia, A.J.; Cochran, J.R. An engineered Axl 'decoy receptor' effectively silences the Gas6-Axl signaling axis. Nat. Chem. Biol. 2014, 10, 977-983. [CrossRef]

113. Kanlikilicer, P.; Ozpolat, B.; Aslan, B.; Bayraktar, R.; Gurbuz, N.; Rodriguez-Aguayo, C.; Bayraktar, E.; Denizli, M.; GonzalezVillasana, V.; Ivan, C.; et al. Therapeutic Targeting of AXL Receptor Tyrosine Kinase Inhibits Tumor Growth and Intraperitoneal Metastasis in Ovarian Cancer Models. Mol. Ther. Nucleic Acids 2017, 9, 251-262. [CrossRef]

114. Divine, L.M.; Nguyen, M.R.; Meller, E.; Desai, R.A.; Arif, B.; Rankin, E.B.; Bligard, K.H.; Meyerson, C.; Hagemann, I.S.; Massad, M.; et al. AXL modulates extracellular matrix protein expression and is essential for invasion and metastasis in endometrial cancer. Oncotarget 2016, 7, 77291-77305. [CrossRef] [PubMed]

115. Mills, K.A.; Quinn, J.M.; Roach, S.T.; Palisoul, M.; Nguyen, M.; Noia, H.; Guo, L.; Fazal, J.; Mutch, D.G.; Wickline, S.A.; et al. p5RHH nanoparticle-mediated delivery of AXL siRNA inhibits metastasis of ovarian and uterine cancer cells in mouse xenografts. Sci. Rep. 2019, 9, 4762. [CrossRef] [PubMed]

116. Guo, Q.; Grimmig, T.; Gonzalez, G.; Giobbie-Hurder, A.; Berg, G.; Carr, N.; Wilson, B.J.; Banerjee, P.; Ma, J.; Gold, J.S.; et al. ATP-binding cassette member B5 (ABCB5) promotes tumor cell invasiveness in human colorectal cancer. J. Biol. Chem. 2018, 293, 11166-11178. [CrossRef] [PubMed]

117. He, L.; Lei, Y.; Hou, J.; Wu, J.; Lv, G. Implications of the Receptor Tyrosine Kinase Axl in Gastric Cancer Progression. OncoTargets Ther. 2020, 13, 5901-5911. [CrossRef]

118. Choi, Y.J.; Kim, J.H.; Rho, J.K.; Kim, J.S.; Choi, C.M.; Kim, W.S.; Son, J.; Lee, J.C. AXL and MET receptor tyrosine kinases are essential for lung cancer metastasis. Oncol. Rep. 2017, 37, 2201-2208. [CrossRef]

119. Hoj, J.P.; Mayro, B.; Pendergast, A.M. A TAZ-AXL-ABL2 Feed-Forward Signaling Axis Promotes Lung Adenocarcinoma Brain Metastasis. Cell Rep. 2019, 29, 3421-3434.e3428. [CrossRef] [PubMed]

120. Taverna, J.A.; Hung, C.N.; DeArmond, D.T.; Chen, M.; Lin, C.L.; Osmulski, P.A.; Gaczynska, M.E.; Wang, C.M.; Lucio, N.D.; Chou, C.W.; et al. Single-Cell Proteomic Profiling Identifies Combined AXL and JAK1 Inhibition as a Novel Therapeutic Strategy for Lung Cancer. Cancer Res. 2020, 80, 1551-1563. [CrossRef]

121. Shibue, T.; Weinberg, R.A. EMT, CSCs, and drug resistance: The mechanistic link and clinical implications. Nat. Rev. Clin. Oncol. 2017, 14, 611-629. [CrossRef]

122. Zheng, X.; Carstens, J.L.; Kim, J.; Scheible, M.; Kaye, J.; Sugimoto, H.; Wu, C.C.; LeBleu, V.S.; Kalluri, R. Epithelial-to-mesenchymal transition is dispensable for metastasis but induces chemoresistance in pancreatic cancer. Nature 2015, 527, 525-530. [CrossRef]

123. Fischer, K.R.; Durrans, A.; Lee, S.; Sheng, J.; Li, F.; Wong, S.T.C.; Choi, H.; El Rayes, T.; Ryu, S.; Troeger, J.; et al. Epithelialto-mesenchymal transition is not required for lung metastasis but contributes to chemoresistance. Nature 2015, 527, 472-476. [CrossRef]

124. Sharma, S.V.; Lee, D.Y.; Li, B.; Quinlan, M.P.; Takahashi, F.; Maheswaran, S.; McDermott, U.; Azizian, N.; Zou, L.; Fischbach, M.A.; et al. A chromatin-mediated reversible drug-tolerant state in cancer cell subpopulations. Cell 2010, 141, 69-80. [CrossRef] [PubMed]

125. Tulchinsky, E.; Demidov, O.; Kriajevska, M.; Barlev, N.A.; Imyanitov, E. EMT: A mechanism for escape from EGFR-targeted therapy in lung cancer. Biochim. Biophys. Acta Rev. Cancer 2019, 1871, 29-39. [CrossRef]

126. De Conti, G.; Dias, M.H.; Bernards, R. Fighting Drug Resistance through the Targeting of Drug-Tolerant Persister Cells. Cancers 2021, 13, 1118. [CrossRef] [PubMed]

127. Tanaka, M.; Siemann, D.W. Gas6/Axl Signaling Pathway in the Tumor Immune Microenvironment. Cancers 2020, $12,1850$. [CrossRef] [PubMed]

128. Mohme, M.; Riethdorf, S.; Pantel, K. Circulating and disseminated tumour cells—Mechanisms of immune surveillance and escape. Nat. Rev. Clin. Oncol. 2017, 14, 155-167. [CrossRef] 